\title{
The perspectives for the use of hydrogen for electricity storage considering the foreign experience
}

\author{
Tomasz Blacharski ${ }^{1}$, Krzysztof Kogut $^{2, *}$ and Adam Szurlej ${ }^{3}$ \\ ${ }^{1}$ Polish Gas Company, Kasprzak Avenue 25, 01-224 Warszawa, Poland \\ ${ }^{2}$ AGH University of Science and Technology, Faculty of Energy and Fuels, Mickiewicz Avenue 30, \\ 30-059 Kraków, Poland \\ ${ }^{3}$ AGH University of Science and Technology, Faculty of Drilling, Oil and Gas, Mickiewicz Avenue \\ 30, 30-059 Kraków, Poland
}

\begin{abstract}
Over the last years, the European Union has seen a rapid increase in installed capacity of generating units based on renewable energy sources (RES). The most significant increase in installed capacity was recorded in 2015, in wind farms and solar PV installations. One of the most serious is the volatile character of RES on a time basis. Therefore, for a further expected increase in the use of RES and their effectiveness improvements, investments are needed allowing for electricity to be stored. One of the electricity storage options is to use excess electricity in order to produce hydrogen by electrolysis of water. Although this process plays a marginal role in obtaining hydrogen on a worldwide basis due to high costs, experience in recent years has shown that periodically low (negative) electricity prices, developing on the power exchanges in the situation where there is surplus electricity available, affect economic requirements for hydrogen production technologies. The paper shows activities undertaken by European countries (mainly Germany) aiming at making it possible for hydrogen to be stored in the natural gas grids. A particular attention is given to material resource issues and possible operational problems that might arise while blending natural gas with hydrogen into the grid. The experiences of selected European countries are of particular interest from the Polish perspective, having regard to significant increase of RES in electricity generation during the last few years and adopted objectives for the growing importance of RES in the Poland's energy balance.
\end{abstract}

\section{Introduction}

The realization of EU energy policy relies on investing in RES-based energy technologies. The dynamics with which RES technologies are used can be traced on the example of the increasing installed power from RES. According to The European Wind Energy Association (EWEA) data of 2015, the highest growth of installed power capacity was observed in wind farms - 12800 MW (i.e. 44.2\% new installed power in EU) and solar parks - $8500 \mathrm{MW}(29.4 \%)$. It is worth noting that in the previous year the power of gas-fed power stations increased only by $6.4 \%$, as

\footnotetext{
* Corresponding author: kogut@agh.edu.pl
} 
compared to the situation ten or so years ago when the investments in gas-based units dominated. It should be also observed that not only West European countries specialize in RES technologies. In 2015 the increase of installed power in wind farms was highest in Germany (6013 MW), i.e. in a country of highest installed power in EU wind farms. Poland occupies the second position in the ranking with its 1266 MW but in Poland $85 \%$ of electricity is still generated from conventional sources, based on hard coal and lignite. A further increase in installed wind farm capacity can lead to a situation in which coal-fired units will reach the limits of their regulatory capabilities, and the power system will become unstable [1-3]. The high dynamics of RES increase can be seen on the example of the indices of annual increase for particular RES technologies used for energy production in the years 1990-2015: photovoltaic cells $-44.1 \%$, wind farms $-22.1 \%$. Total participation of RES in the World's electrical energy production in 2014 equaled to $22.3 \%$ and was second of magnitude after coal with its $40.7 \%$. In the years 1990-2014 the average annual increase of electrical energy generated by RES installations remained on the level of $3.6 \%$, with the global increase of electrical energy production of $2.9 \%$ [4]. In 2015 the World's highest increase of RES was observed in the wind farms (from $370 \mathrm{GW}$ at the close of 2014 to $433 \mathrm{GW}$ ), and in photovoltaics from $177 \mathrm{GW}$ to $227 \mathrm{GW}[5]$.

Figure 1 illustrates changes of the electricity generation in Poland and in Germany in the years 2005 and 2015 .
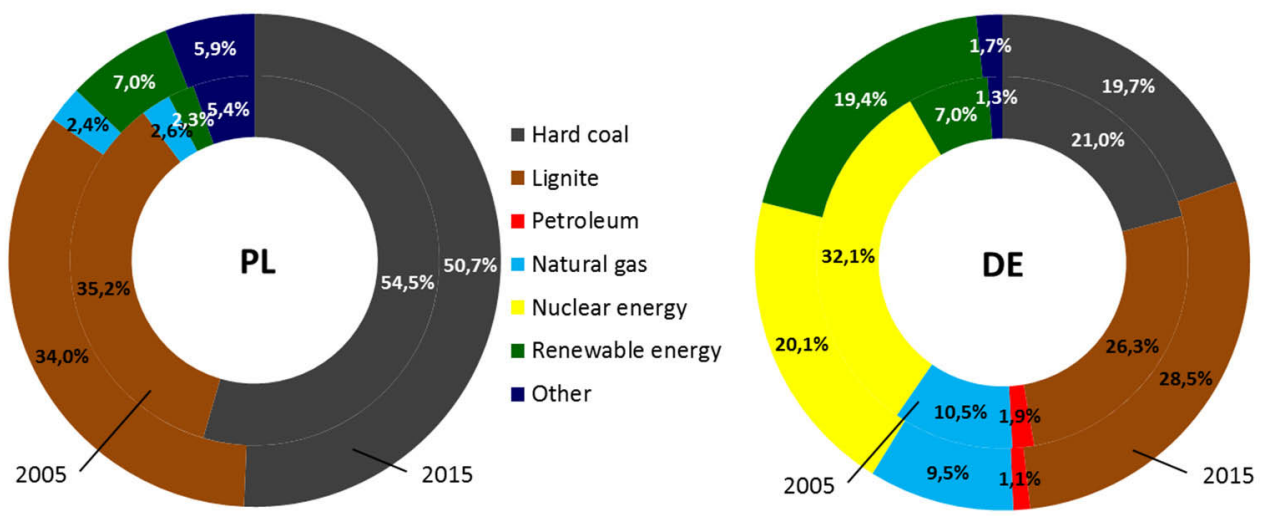

Fig. 1. Structure of electricity generation in Poland and Germany [own analyses based on 6-9]

The analysis of figure 1 reveals that the participation of RES is systematically increasing. The growing share of RES is connected with the fact that electricity is generated very unevenly because of the varying atmospheric conditions [10]. Frequently the period of low energy demand (e.g. holiday time) coincides with a high productivity time, and in the high demand periods (e.g. evening hours) the production drops down. Solving of this issue is very important in view of the planned development of RES applications.

\section{Storing of electrical energy}

Storing of electrical energy is frequently associated with batteries, accumulators or energy of water. Among other available methods of energy storing are [11]:

- Electrical energy - making use of condensers, super condensers (DLC) or Superconducting Magnetic Energy Storage (SMES), 
- Mechanical energy - starting from pumped-storage hydroelectricity (PSH) and flywheels (FES), through springs and Compressed Air Energy Storage (CAES), to hydraulic accumulators,

- Chemical energy - biofuels, synthetic fuels, synthetic methane (SNG), methanol or hydrogen $(\mathrm{H} 2)$,

- Electrochemical energy - lead accumulators (LA), Li-Ion accumulators, sodium accumulators (NaS, NaNiCl), nickel accumulators (BEV); Redox Flow Batteries (RFB) and fuel cells,

- Thermal energy - latent heat of melted salt

Figure 2 gives a comparison of rated electrical power, time of use of stored energy and amount of collected energy in various technologies of storing.

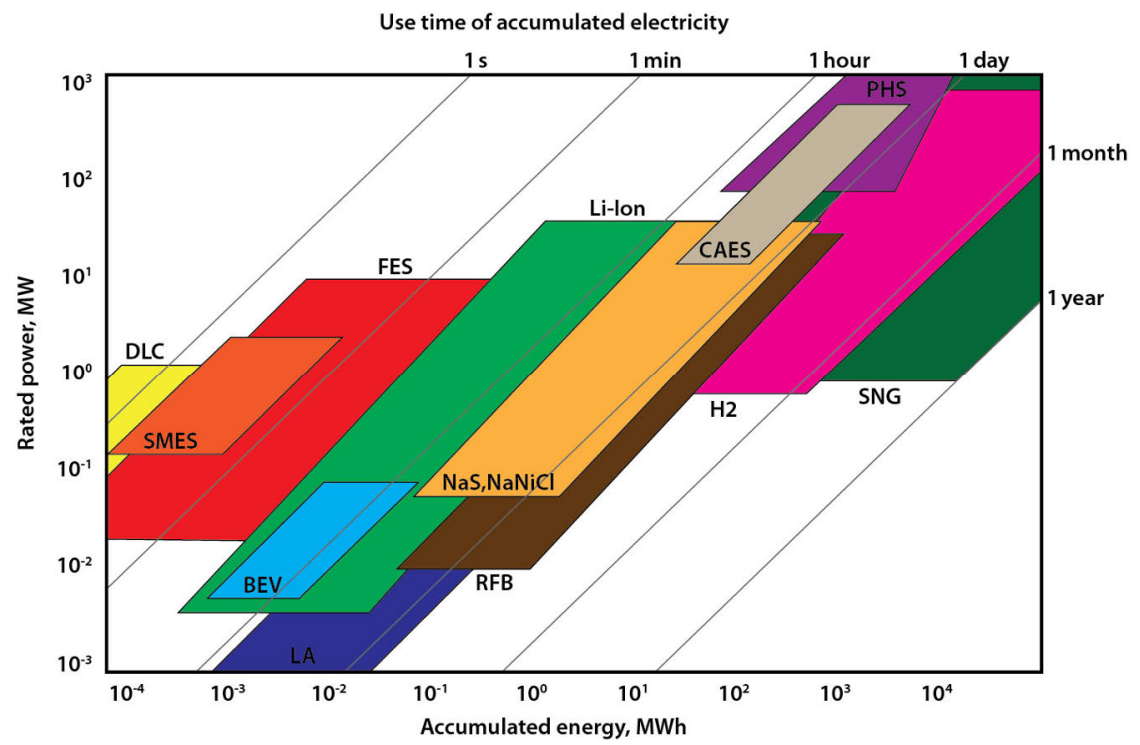

Fig. 2. Comparison of various technologies of storing electrical energy [11, 12]

\section{Storing of hydrogen}

As presented in figure 2 the longest time of energy storing allows one to use hydrogen in the pure molecular form, and bounded in natural gas (SNG) after prior methanization $(1,2)$ :

$$
\begin{gathered}
\mathrm{CO}_{2}+4 \mathrm{H}_{2} \rightarrow \mathrm{CH}_{4}+2 \mathrm{H}_{2} \mathrm{O} \\
\mathrm{CO}+3 \mathrm{H}_{2} \rightarrow \mathrm{CH}_{4}+\mathrm{H}_{2} \mathrm{O}
\end{gathered}
$$

Additionally, the use of hydrogen allows for storing largest quantities of energy and obtaining highest electrical power. Technically, this technology is most advantageous.

One of the newest such technologies is Power to Gas.

\subsection{Power to Gas}

In this technology the electrical energy can be converted into gaseous fuel. The Power to Gas concept has been presented in figure 3 . 


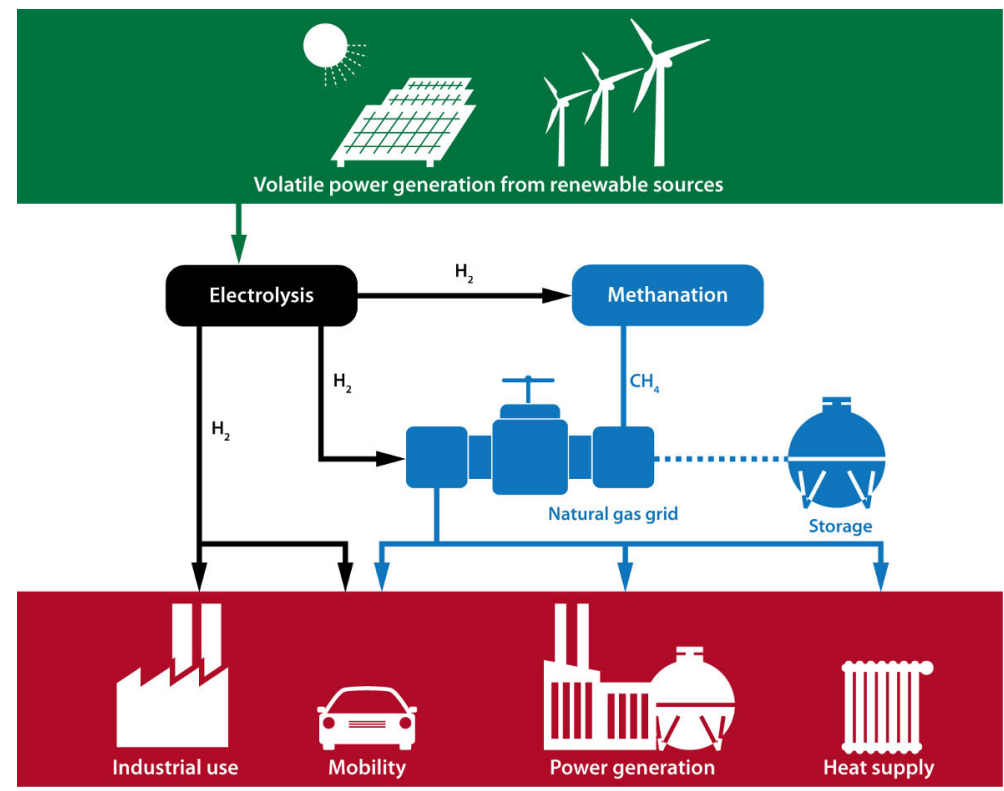

Fig. 3. Power to Gas solution [own preparation based on 13, 14]

The excess of RES electrical energy, most frequently produced in periods of lower energy demand, is used for hydrolyzing water with of one of the presently available methods (alkaline electrolysis, proton exchange diaphragm electrolysis, solid oxide electrolysis cell), which will be briefly discussed further in this paper.

\subsection{Technical problems - storing of hydrogen}

Owing to its properties, the storing, transmission and ultimate use of hydrogen create considerable problems. These are purely material problems caused by the smaller size of the hydrogen particle as compared to, e.g. methane, which is a dominating component of natural gas. The diverse combustible properties of hydrogen have to be also accounted for. For this reason the risk analysis should be performed for transmission of hydrogen $[15,16]$.

When the gas interacts with the pipes or container, there is a risk that hydrogen may locate inside the crystalline structure of steel. In the case of steel pipes the hydrogen corrosion is also dangerous as it leads to the formation of cracks and diffusion of hydrogen particles outside the tank. Synthetic pipes (PE, PA11) also create problem as they are more liable to leakages than their steel counterparts [17], though their mechanical strength remains on the same level $[18,19]$.

Apart from material and strength issues, one should also account for the impact of hydrogen on parameters, which are important for:

- transport - viscosity, density, specific heat, Joule-Thomson coefficient,

- combustion - burning heat, Wobbe index, flammability, regular combustion rate, minimum ignition energy, etc.,

- measurement - for gas meters and recalculation devices or gas analyzers.

The degree of preparation of particular groups of elements working together (transmission, storing, use) in a function of hydrogen content is presented in figure 4. 

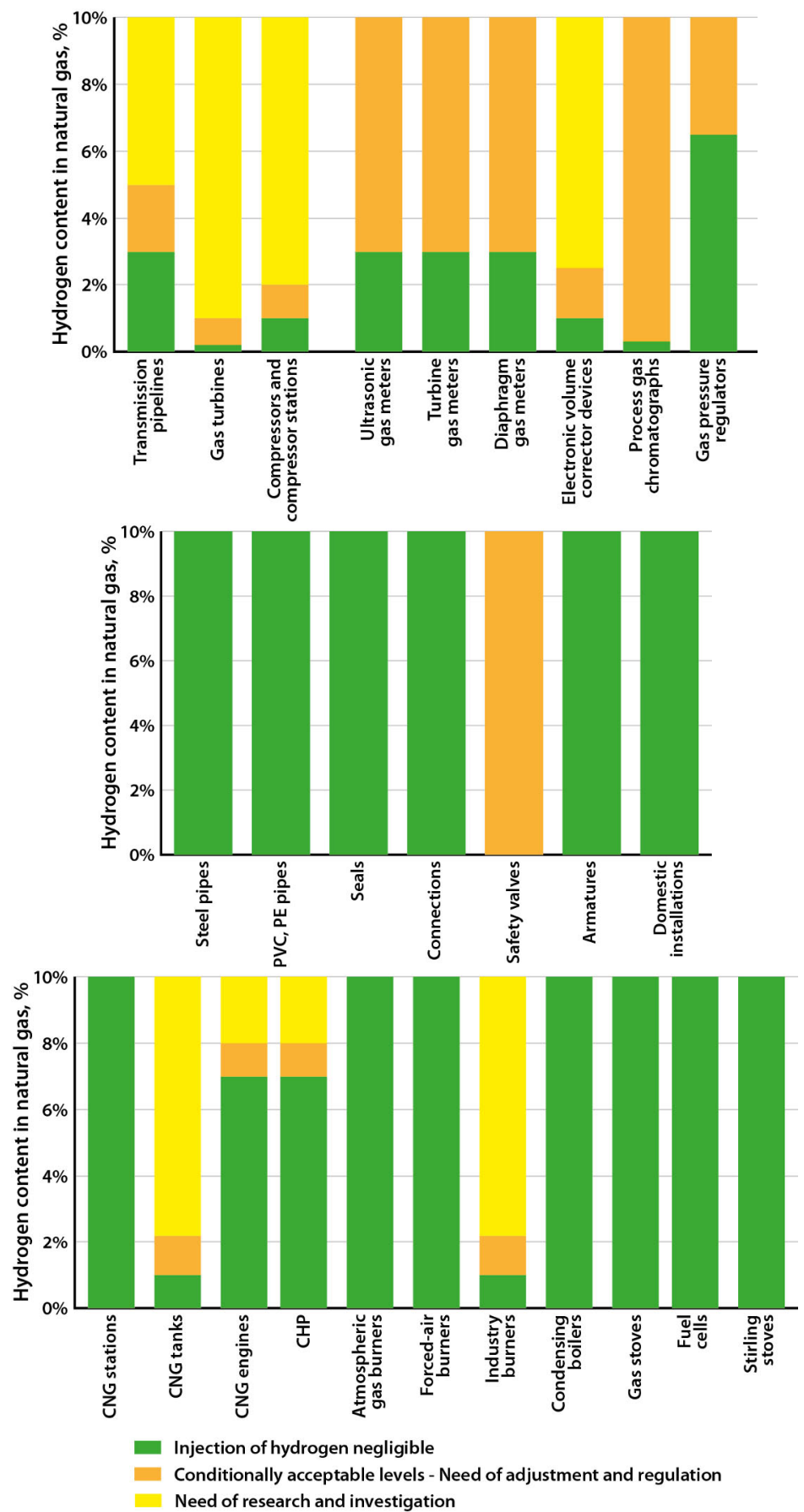

Fig. 4. Adjustment of devices in particular gas delivery segments (transmission, distribution, use) in a function of hydrogen content in natural gas [20]

Most of the elements of the gas transmission-use system can transport natural gas with small quantities of nitrogen. The most difficult situation can be encountered in the case of gas turbines, process chromatographs used for determining gas composition, or gas leakage detection systems [21]. 
The influence of the increasing hydrogen content in high-calorific natural gases used in Poland on the change of major parameters determining the possibility of transmitting gas through the gas pipeline network is presented in figure 5. The influence of a hydrogen concentration reaching up to $50 \%$ was analyzed. 'Domestic gas' (E) is produced in Poland and belongs to the E group of gases. 'East gas' has parameters of gas imported from Russia, whereas 'mean gas' has features of a mixture of imported and $\mathrm{E}$ gas.

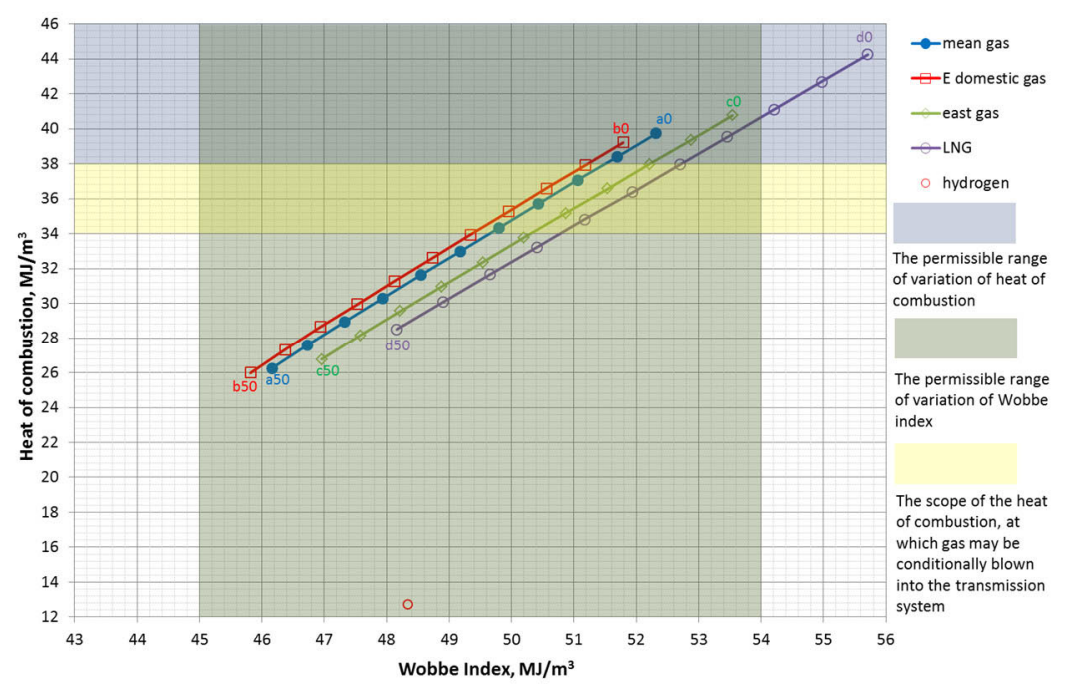

Fig. 5. Change of burning heat value and Wobbe index under the influence of increasing participation of hydrogen, depending on type of gas. " 0 " - clean gas, " 50 " - $50 \%$ hydrogen content in gas, change of hydrogen content every $5 \%$ [own analysis based on 22,23 ]

There is a danger that after adding ca. $10 \%$ of hydrogen to natural gas the latter will not meet the requirements of the Economy Minister regulation [MG_2010]. In the case of the gas pipelines, where the transmitted natural gas flows in considerably bigger streams, the risk of making the gas unfit is much lower than in the distribution networks [21, 22].

\subsection{Production of hydrogen - selected technical and economic aspects}

At present most of the World's hydrogen is produced with the use of the methane reforming with steam. The popularity of natural gas in hydrogen production stems from, e.g. low cost of production (low cost of investment and exploitation), lowest $\mathrm{CO}_{2}$ coproduction per mole of obtained hydrogen, and also natural gas resources [24]. Considering the dynamic development of RES, observed mainly in the EU countries, one should expect an increased production of hydrogen through electrolysis - a way of managing excess of electrical energy from RES. Typically for the RES technologies, the work does not go uniform. The electrolysis itself is a very energy-consuming process. The following types of professional electrolyzers are used [25-27]:

- alkaline - water solution of hydroxide, most frequently $\mathrm{KOH}$ or rarely $\mathrm{NaOH}$, is the electrolyte, electrodes are separated with a porous diaphragm to stop mixing of generated hydrogen and oxygen. The process is conducted at a temperature of $70-80^{\circ} \mathrm{C}$ and atmospheric pressure, and at a temperature of $90-100^{\circ} \mathrm{C}$ in pressure electrolyzers; the efficiency is of $70 \%$,

- polymeric PEM - polymeric diaphragm of high ionic conductance is used in the process with hydrogen ions (protons) as charge carriers; hydrogen is produced on the cathode 
while the electrolyzer is operating. The process is conducted at a temperature of $70-80^{\circ} \mathrm{C}$, the efficiency equals to $70-80 \%$, and the obtained hydrogen has purity of the level of 99.999\%.

Table 1 summarizes the main characteristics of alkaline and PEM electrolysis systems.

Table 1. Parameters of typical water electrolysis cells [26]

\begin{tabular}{|l|c|c|}
\hline Electrolysis process & Alakline & PEM \\
\hline Ions transport & Hydroxyl $\mathrm{OH}^{-}$ & Protons $\mathrm{H}^{+}$ \\
\hline Anode reaction & $4 \mathrm{OH}_{(a q)}^{-} \rightarrow \mathrm{O}_{2(g)}+2 \mathrm{H}_{2} \mathrm{O}_{(l)}$ & $2 \mathrm{H}_{2} \mathrm{O}_{(l)} \rightarrow 4 H_{(a q)}^{+}+\mathrm{O}_{2(g)}+4 e^{-}$ \\
\hline Cathode reaction & $2 \mathrm{H}_{2} \mathrm{O}_{(l)}+2 e^{-} \rightarrow \mathrm{H}_{2(g)}+2 \mathrm{OH}_{(a q)}^{-}$ & $4 H_{(a q)}^{+}+4 e^{-} \rightarrow 2 \mathrm{H}_{2(g)}$ \\
\hline
\end{tabular}

At present the commercial solutions bring about over $80 \%$ energy efficiency [28]. Advantageously for this technology, the process can be performed economically if the cost of the provided electrical energy is lower than the marker price. The analysis of table 2 reveals that the cost of electrical energy dominates in the structure of hydrogen production through electrolysis. Considering the high dynamics of RES investments, characterized by uneven production of electrical energy, the electrical energy prices may drastically drop down to even reach negative values in a situation of high energy sales from RES installations (mainly wind farms and photovoltaic parks), at moderate demand for energy (e.g. holiday time). This can be evidenced by a detailed analysis of electrical energy prices on the German market as of 8 May 2016 (Sunday), and visualized in figure 6. On this day the RES-based energy technologies covered the afternoon demand for electricity (only solar parks generated about $26 \mathrm{GW}$ of power supplied at 1 p.m., so higher than maximum demand of Poland in 2015, i.e. $25.1 \mathrm{GW}$ of 7 January 2015) [8]. At a low demand for electrical energy on 8 May 2016, the RES installations covered over $90 \%$ of demand for electrical energy in Germany (exceptionally high participation) in particular hours of the day.

Table 2. Structure of hydrogen production [\%] through steam reforming and electrolysis (polymeric electrolyzer) [after 29, 30]

\begin{tabular}{|l|c|c|}
\hline \multicolumn{1}{|c|}{ Production cost category } & Steam reforming & Electrolysis \\
\hline Capital charges & 29 & 15 \\
\hline Fuel and electricity & 61 & 78 \\
\hline Operation and maintenance & 10 & 7 \\
\hline
\end{tabular}

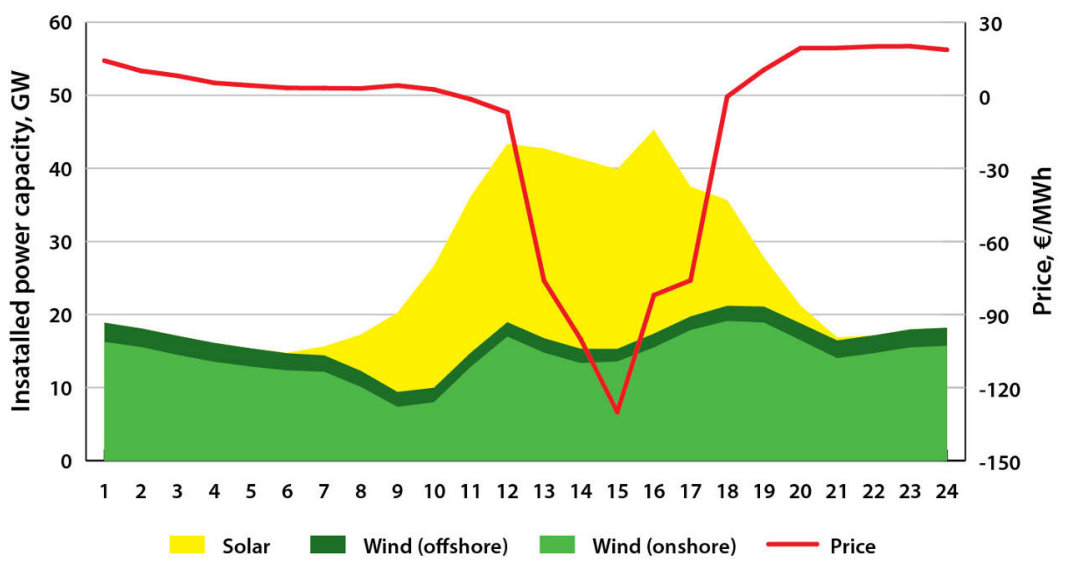

Fig. 6. Prices and production of electrical energy from RES in Germany on 8 May 2016 [31, 32] 
Judging from German experience, the development of the use of RES and varying electrical energy prices, in that negative prices, may have impact on the economic attractiveness of hydrogen production through electrolysis. The analysis of hydrogen production through electrolysis presented in [33] shows that the lowest values were observed in nuclear plants - 4.15 USD $/ \mathrm{kg}$, higher for wind farms - about $6 \mathrm{USD} / \mathrm{kg}$ and highest for solar parks -7 to $10.5 \mathrm{USD} / \mathrm{kg}$. The comparison of hydrogen production through electrolysis and other technologies based on coal (gasification), or natural gas (steam reforming) reveals the dominance of technologies based of fossil fuels. In the case of electrolysis-based technology the cost of electrical energy dominates in the hydrogen production budget, whereas in the case of reforming the cost of natural gas prevails, totaling to about $60 \%$. Thus a drop of natural gas prices observed over the last years, especially on the American market as a consequence of the shale gas revolution, made the World's popular hydrogen technology even more attractive [32-35].

It should be emphasized that thanks to the use of innovative solutions in the production of electrolyzers the capital costs relating to their production were significantly lowered from over $2500 \mathrm{USD} / \mathrm{kW}_{\mathrm{e}}$ (2001) to less than $400 \mathrm{USD} / \mathrm{kW}_{\mathrm{e}}$ (2012) [29].

Hydrogenics and Proton Motor are typical examples of companies producing electrolyzers on a commercial scale. In April 2013 Hydrogenics Corporation announced that for the first time on the World's scale they used a PEM electrolyzer 1 MW for storing energy, as ordered by E.ON in Hamburg. The installation will be used for hydrogen production with the use of excessive electrical energy from RES, mainly from wind farms. On 15 October 2015 a 1.5 MW unit started its operation in Hamburg (also employing PEM electrolyzer) [36]. Tables 3 and 4 contains selected technical data of various electrolyzers - alkaline and PEM respectively.

Table 3. Selected technical data of illustrative alkaline electrolyzers [after data provided by 36-41]

\begin{tabular}{|l|c|c|c|c|c|c|}
\hline \multirow{2}{*}{ Parameter } & \multirow{2}{*}{ Unit } & \multicolumn{5}{|c|}{ Model } \\
\cline { 3 - 7 } & & $\begin{array}{c}\text { HyProvide } \\
\text { A60- }\end{array}$ & S-556 & $\begin{array}{c}\text { HySTAT-60- } \\
\mathbf{1 0}\end{array}$ & A-300 & $\begin{array}{c}\text { TITAN } \\
\text { EL-N }\end{array}$ \\
\hline Manufacturer & & GreenHydrogen & IHT & Hydrogenics & NEL Hydrogen & Teledyne \\
\hline Pressure & barg & 30 & 32 & 10 & 250 & 9 \\
\hline Number of piles & & 1 & NA & 4 & NA & NA \\
\hline Max $\mathrm{H}_{2}$ flow rate & $\mathrm{m}^{3} / \mathrm{h}$ & 60 & 760 & 60 & 300 & 500 \\
\hline Installed power & $\mathrm{kVA}$ & 270 & ca. 3420 & $2 \times 240+35$ & 1300 & NA \\
\hline Purity of $\mathrm{H}_{2}$ & $\%$ & 99.995 & NA & 99.998 & 99.9 & 99.999 \\
\hline $\mathrm{H}_{2} \mathrm{O}$ consumption & $1 / \mathrm{m}^{3} \mathrm{H}_{2}$ & 1.0 & NA & $1.5-2$ & 0.9 & 1.0 \\
\hline Weight & $\mathrm{Mg}$ & ca. 3.5 & NA & ca. 16 & NA & NA \\
\hline
\end{tabular}

Table 4. Selected technical data of illustrative PEM electrolyzers [after data provided by 42-44]

\begin{tabular}{|l|c|c|c|c|}
\hline \multirow{2}{*}{ Parameter } & \multirow{2}{*}{ Unit } & \multicolumn{3}{c|}{ Model } \\
\cline { 3 - 5 } & & C 30 & McLyzer S 18 MP & Mercury G192 \\
\hline Manufacturer & & Proton OnSite & McPhy & ErreDUE \\
\hline Pressure & barg & 30 & 12 & 30 \\
\hline Number of piles & & 1 & 1 & 1 \\
\hline $\mathrm{H}_{2}$ flow rate & $\mathrm{m}^{3} / \mathrm{h}$ & 30 & 12 & 128 \\
\hline Installed power & $\mathrm{kVA}$ & 275 & 63 & 684 \\
\hline Purity of $\mathrm{H}_{2}$ & $\%$ & 99.9998 & 99.999 & 99,9995 \\
\hline $\mathrm{H}_{2} \mathrm{O}$ consumption & $1 / \mathrm{m}^{3} \mathrm{H}_{2}$ & 0.90 & 0.83 & 0.84 \\
\hline Weight & $\mathrm{Mg}$ & 3 & 1.5 & 11.4 \\
\hline
\end{tabular}


In the case of the most advanced model of the yield $60 \mathrm{~m}^{3} / \mathrm{h}$ and a relatively small stream of gas in the pipeline (ca. $10000 \mathrm{~m}^{3} / \mathrm{h}$ ), the obtained hydrogen concentration in natural gas remains on a level of $6 \%$ at most. Only when some electrolyzers are used at the same time the hydrogen concentration equals to a few percent (the flow rate of $10000 \mathrm{~m}^{3} / \mathrm{h}$ ).

Obviously, if the same model is applied and hydrogen is pumped to the distribution gas pipeline, where the flowing stream is much smaller, the hydrogen concentration will be respectively higher.

\section{Conclusions}

The realization of goals of the EU energy policy, sustained development and reduced resources of fossil fuels will have influence on the direction of changes in the energy sector. In the times of an intense increase of installed power capacity in RES-based technologies, the storing of electrical energy is the most important problem to be solved. As shown in the paper, there are many methods of storing electrical energy and numerous research works nowadays concentrate on increasing their efficiency. One of the most interesting energy storage solutions is the Power to Gas concept. German experience shows to the increasing significance of this technology manifesting itself in a higher capacity of the electrolyzers, higher number of installations and hydrogen production through electrolyzers. A broader use of the Power to Gas technology is interesting to companies representing the natural gas sector. Over the last few years the demand for natural gas has lowered in many European countries, except Poland. Thus the development in of Power to Gas projects will contribute to the increase of use of the existing gas infrastructure, which shall have influence on the higher efficiency of work of the energy sector. However, considering the specific properties of hydrogen, mainly before it is introduced to the gaseous networks, a polydimensional analysis should be performed in view of the risk accompanying transport of a mixture of natural gas and hydrogen. The plans of the Polish government regarding the more intense use of electrical vehicles and planned sales of hydrogenfed vehicles by one of the World's leading concerns may be important factors giving spur to the use of the Power to Gas technology in Poland.

\section{References}

1. EWEA, Wind in Power: 2015 European statistics (2016), www.ewea.org

2. Ł. Bartela, J. Kotowicz, K. Dubiel, Journal of Power Technologies, 96, 2, 92-100 (2016)

3. J. Kotowicz, Ł. Bartela, D. Węcel, K. Dubiel, Energy, 118, 156-171 (2017)

4. IEA, Key Renewables Trends Excerpt from: Renewables information (Pairs, 2016)

5. REN21, Renewables 2016 Global status report (2016)

6. www.mg.gov.pl

7. Raport Prezesa URE (2016); www.ure.gov.pl

8. Polskie Sieci Elektroenergetyczne; www.pse.pl

9. DIV Berlin, EEFA, Evaluation tables of the energy balance for Germany (2016)

10. J. Kotowicz, M. Jurczyk, D. Węcel, W. Ogulewicz, Journal of Power Technologies, 96, 3, 149-156 (2016)

11. K. Hajdrowski, Energia elektryczna, 11, (2012)

12. http://forschung-energiespeicher.info/en/wind-to-hydrogen/project-list/projectdetails//Stacks_auf_Herz_und_Nieren_testen/, (2016)

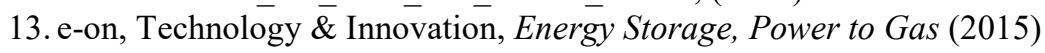

14. Hydrogenics, Power-to-Gas Solution (2012)

15. A. Rusin, K. Stolecka, Rynek Energii, 3, 87-93 (2011) 
16. T. Włodek, M. Łaciak, K. Kurowska, Ł. Węgrzyn, AGH Drilling, Oil, Gas, 33, 2, 379396 (2016)

17. M.H. Klopffer, P. Berne, S. Castagnet, M. Weber, G. Hochstetter, E. Espuche, Polymer Pipes for Distributing Mixtures of Hydrogen and Natural Gas: Evolution of their Transport and Mechanical Properties after an Ageing under an Hydrogen Environment (1 $8^{\text {th }}$ World Hydrogen Energy Conference, Essen, 2010)

18. S. Castagnet, J.C. Grandidier, M. Comyn, G. Benoit, Int. J. Pres. Ves. Pip. 89, 203-209 (2012)

19. M. Ball, A. Basile and T. N. Veziroglu (ed.), Compendium of Hydrogen Energy (Elsevier) (2015)

20. G. Müller-Syring, M. Henel, Wasserstofftoleranz der Erdgasinfrastruktur inclusive aller assoziierten Anlagen (2014)

21. T. Blacharski, P. Janusz, M. Kaliski, Ł. Zabrzeski, AGH Drilling, Oil, Gas, 33, 2, 515 528 (2016)

22. Rozporzadzenie Ministra Gospodarki z dnia 2 lipca 2010 r. w sprawie szczegółowych warunków funkcjonowania systemu gazowego, Warszawa (2010)

23. https://swi.gaz-system.pl/swi/public/, (5 IX 2016)

24. T. Borowiecki, A. Gołębiowski, P. Kowalik, J. Ryczkowski, Przem Chem, 8, 1306-1315 (2015)

25. A. Małek, Ł. Grabowski, K. Pietrykowski, R. Sochaczewski, G. Barański, M. Szlachetka, M. Gęca, Autobusy, Technika, Eksploatacja, Systemy transportowe, 10, 305-310 (2011)

26. I. Dincer, Int J Hydrogen Energ 37, 1954-1971 (2012)

27. D.M.F. Santos, C.A.C. Sequeira, J.L. Figueiredo, Quim. Nova, 36, 1176-1193 (2013)

28. S.A. Sherif, D. Yogi Goswami, E.K. Stefanakos, A. Steinfeld, Handbook of Hydrogen Energy, (Taylor \& Francis Group, 2015)

29. D.R. Peterson, P. Zelenay, Overview of U.S. Department of Energy Efforts on Hydrogen Production from Water Electrolysis. (ElectroHyPEM Workshop, Taormina, 2014)

30. K. Schoots, F. Ferioli, G.J.Kramer, B.C.C.van der Zwaan, Int J Hydrogen Energ 33, 26302645 (2008).

31. http://www.epexspot.com/en/market-data/dayaheadauction/chart/auction-chart/2016-0508/DE (2016)

32. https://www.eex-transparency.com/homepage/power/germany/production/usage/solarwind-power-production/solar-wind-power-production-chart (2016)

33. P. Nikolaidis, A. Poullikkas, Renew Sust Energ Rev 67, 597-611 (2017)

34. E. Gross-Gołacka, W. Lubiewa-Wieleżyński, A.P. Sikora, A. Szurlej, R. Biały, Przem Chem, 92, 1393-1398 (2013)

35. A. Szurlej, P. Janusz, Gospod Surowcami Min, 29, 4, 77-94 (2013)

36. Hydrogenics, Hydrogenics to Install World's First Megawatt PEM Electrolyser for E.ON Power-to-Gas Facility (2013), http://www.fuelcelltoday.com

37. HyProvide ${ }^{\mathrm{TM}}$ A60, (2016), http://www.greenhydrogen.dk

38. S-556, (2016), http://www.iht.ch

39. M. Bodner, A. Hofer, V. Hacker, WIREs Energy Environ, , 365-381 (2015)

40. A-300, http://www.nelhydrogen.com

41. Titan ${ }^{\mathrm{TM}}$ EL-N Series, (2016), http://www.teledynees.com

42. Proton OnSite, Hydrogen Generation Systems. C Series. Technical Specifications. (2016), http://www.protononsite.com

43. http://www.mcphy.com

44. ErreDUE, Mercury - Hydrogen generators, (2016), http://www.erreduegas.com 